China Perspectives

$2010 / 2$ | 2010

Gao Xingjian and the Role of Chinese Literature Today

\title{
Editorial
}

\section{Sebastian Veg}

\section{(2) OpenEdition}

Journals

Édition électronique

URL : http://journals.openedition.org/chinaperspectives/5265

DOI : 10.4000/chinaperspectives.5265

ISSN : 1996-4617

\section{Éditeur}

Centre d'étude français sur la Chine contemporaine

\section{Édition imprimée}

Date de publication : 1 juin 2010

ISSN : 2070-3449

Référence électronique

Sebastian Veg, "Editorial », China Perspectives [En ligne], 2010/2 | 2010, mis en ligne le 05 août 2010, consulté le 23 septembre 2020. URL : http://journals.openedition.org/chinaperspectives/5265 ; DOI : https://doi.org/10.4000/chinaperspectives.5265

(C) All rights reserved 


\section{Editorial}

SEBASTIAN VEG

$\mathrm{C}$ hinese literature and its significance or insignificance is a continued subject of heated debate in China. From May Fourth, when anti-traditionalist thinkers called on literature to assume a pioneering role in transforming subjects into citizens, to its use as propaganda during World War Two and on both sides of the Strait after 1949, it was seen as a crucial vector of political ideas. During the "Enlightenment" of the 1980s, literature was again called upon to play a central - though politically very different - role in helping society come to terms with the officially still taboo traumas of the Cultural Revolution. However, "Enlightenment" this time was not only synonymous with anti-traditionalism: critical reflection on the iconoclasm of the Cultural Revolution, emphasizing literature's role as a moral conscience, also led to an enthusiastic rediscovery of cultural tradition, often against May Fourth ideals, among the writers of the "roots" (xungen) movement. It was only in the aftermath of the failed Tiananmen protests of 1989 that younger writers began to substantially question the need for literature to play a central role in society and in intellectual debate.

Perhaps inevitably, while its significant social role was extolled, debates about Chinese literature were routinely accompanied by anguished doubts about its intrinsic, aesthetic, or intellectual value, whether because of its alleged break (voluntary or as the result of an irresistible historical trend) with Chinese tradition or, on the contrary, because of its continued subordination of aesthetic autonomy - viewed as a defining aspect of the "high modernism" that ensures writers international recognition - to socio-political concerns. Soul-searching about why Chinese writers did or did not deserve a Nobel Prize for Literature took place throughout the 1980s and into the 1990s, with official organs such as the Writers' Association actively lobbying on behalf of members such as Ba Jin and Ai Qing. Liu Xiaobo on the other hand, then the "angry young man" of Chinese literary criticism, in a talk at the literature Research Institute of the Chinese Academy of Social Sciences (chaired by Liu Zaifu) in 1986 and several subsequent articles attacking "scar literature" and the roots writers, also called for an end to Chinese writers' "childish" obsession with the Nobel Prize. (1)

Liu Zaifu, in a series of articles written on the eve of the hundredth anniversary of the literature prize, underscored the long history and great value of Chinese literature and un- abashedly called for international institutional recognition of its qualities before the Prize's count of years reached one hundred. ${ }^{(2)}$ Writing about his visit to Sweden at the invitation of Göran Malmqvist, Liu discusses the merits of $\mathrm{Lu}$ Xun, Li Jieren, and Shen Congwen before going on to mention contemporary authors Bei Dao, Gao Xingjian, and Li Rui as favourites of Malmqvist. The Swedish academy's choice of Gao Xingjian the very next year as the laureate of the one hundredth anniversary prize appeared to many as a carefully balanced rejoinder to these criticisms: while awarding the prize to a culturally and linguistically Chinese writer who, although he had lived in China for almost 50 years and written largely within the context of contemporary Chinese literature, now held French citizenship and also wrote in French, the Nobel committee seemed to be explicitly rejecting, just as Gao had in his own essays, the idea that the Nobel prize should be "representative" in any way of a nation-state or its literary field. At first, there seems to have

1. See Wendy Larson and Richard Kraus, "China's Writers, the Nobel Prize, and the International Politics of Literature," The Australian Journal of Chinese Affairs, no. 21 (Jan., 1989), pp. 143-160. The authors detail the story of the Jinshan conference in November 1986 near Shanghai, to which the Chinese authorities invited Göran Malmqvist, who had just joined the Nobel Academy (pp. 13-14). See also Liu Xiaobo's articles "Weiji! Xin shiqi wenxue mianlin weiji" (Crisis! The Literature of the New Age is Facing a Crisis), Shenzhen qingnianbao, 3 October 1986 and "Zai Iun xin shiqi wenxue mianlin weiji: guanyu 'Weiji' yiwen de jidian buchong" (Another discussion about the crisis faced by literature in the new era: a few additional points to "Crisis"), Baijia, No. 1, 1988, p. 12-26 (quoted by Larson and Kraus, art. cit., p. 152-153). See also Geremie Barmé, "Confession, Redemption, and Death: Liu Xiaobo and the Protest Movement of 1989" in George Hicks (ed.), The Broken Mirror: China After Tiananmen, London, Longmans, 1990, pp. 52-99.

2. See Liu Zaifu, "Bai nian Nuobei'er wenxue jiang he Zhongguo zuojia de quexi” (One hundred years of Nobel Prize and the absence of Chinese writers), Lianhe wenxue, 1999 (in particular parts VI on Republican authors, VII on contemporary Chinese authors, and VIII on Taiwanese and Hong Kong authors). Available online on Liu Zaifu's blog at http://blog.sina.com.cn/s/blog_4cd081e90100f8bg.html (28 May 2010).

3. The Foreign ministry spokesperson declared that the choice of Gao "shows again the Nobel Literature Prize has been used for ulterior political motives, and it is not worth commenting on." The Writers' Association spokesperson Jin Jianfan reacted as follows: "He [Gao] is French and not Chinese and the reason he won the award is more political than literary. There are hundreds of Chinese writers who are better than him, which proves that the committee is very ignorant." See "Beijing attacks 'political' literature award," BBC News, 13 October 2000, http://news.bbc.co.uk/2/hi/europe/970184.stm. To add a personal anecdote, when the Nobel Prize was announced, I happened to be teaching in the French Department of Beijing Foreign Studies University, Gao's alma mater and former department, where several colleagues remembered him well. When the official verdict was handed down, at least one of Gao's former colleagues, based on his earlier memories, began holding forth to all and sundry (in particular his students) about Gao's bad language skills in French, which he assumed to be the language in which his novels had been written. This proved beyond doubt, in his opinion, the political nature of the prize that had been awarded. 
been significant tension within the Chinese literary-political establishment as to how to react to the Nobel Prize (announced on 12 October 2000): the nominal president of the writers' association was still Ba Jin, who at 96 and in ill health could not, or at any rate did not, speak out. The government came out against the prize, denouncing the academy's decision as political and branding the recipient as a French writer (October 13), thereby instilling doubts among many mainland readers, who lacked access to Gao's most recent texts and in particular his two novels, as to whether he still wrote in Chinese. ${ }^{(3)}$ However, Premier Zhu Rongji, in the course of a long press conference held during a visit to Japan on the evening of October 14, congratulated the laureate as well as the French Ministry for Culture, perhaps because he was not sufficiently informed of the line decided in Beijing, or because he personally disagreed with it. ${ }^{(4)}$ Others, including critics Liu Zaifu and writer Mo Yan, congratulated Gao Xingjian, echoing the resounding endorsement of the prize in Hong Kong and especially Taiwan, where Gao Xingjian has now achieved cult-like status.

More importantly, the prize reignited a century-old polemic on Chinese literature's "special relationship" with the nation and its difficulty in attaining universal significance, well know to Western critics through the strongly worded views of C. T. Hsia. Hsia, whose History of Modern Chinese Fiction was first published in 1961, bluntly stated in his afterword to the third edition in 1999 that the "obsession with China" that in his view characterises modern Chinese literature allows it, at best, to share -"a spiritual affinity with the most significant modern Western literature, despite its explicit denial of universality." ${ }^{(5)}$ At the other end of the ideological spectrum, Fredric Jameson, after visiting Beijing in 1986, famously averred that because it always speaks for the oppressed national community as a whole, "the Third World novel will not offer the satisfactions of Proust or Joyce; what is more damaging than that perhaps, is its tendency to remind us of outmoded stages of our own first-world cultural development." ${ }^{(6)}$ Julia Lovell, the first Western scholar to devote a book-length study to "China's quest for a Nobel Prize in literature," similarly focuses on what she views as the Nobel committee's hypocrisy in highlighting the "universal value" of Gao's writings while in fact rewarding his stance as a "closet dissident" who, despite his ostensible stance as an apolitical writer of non-national literature, in fact remains "obsessed with China" (and therefore, no doubt, unworthy of the prize). ${ }^{(7)}$ Regardless of how one judges the quality of Gao's writing, or modern Chinese literature in general, one cannot help wondering if there is not an implicit misunder- standing in these pronouncements: the universal appeal of a literary work is surely not incompatible with an author's deep engagement with one (or even possibly more than one) particular society or culture. In any case, it is safe to conclude that the 2000 Nobel Prize did not put an end to the polemics about the international position of Chinese literature, but only fanned them further, with Gao Xingjian's name even being omitted from some lists of Nobel laureates in China. ${ }^{(8)}$ More recently, one might add, discussion of the value of Chinese literature was rekindled by an interview with German sinologist Wolfgang Kubin for the Chinese-language service of German broadcaster Deutsche Welle in the fall of 2006, in which Kubin criticised - in no uncertain terms excessive Western interest in contemporary Chinese fiction (in particular what he described as commercial fiction such as works by Wei Hui and Mian Mian), to the detriment of other genres such as contemporary poetry and Republican fiction. The huge impact that this rather brief interview with an obscure European public radio broadcaster sparked in China ${ }^{(9)}$ once again revealed the importance, in the eyes of

4. This was reported in a Hong Kong pro-Beijing newspaper: "Zhu Rongji miaoyu huajie bairen jienan" (Zhu Rongji's elegant words defuse one hundred reproving questions), Dongfang Ribao (Oriental Daily), 15 October 2000, p. A8. Zhu Rongji is quoted as follows: "I am very pleased that a literary œuvre written in Chinese was awarded the Nobel Prize. Chinese characters have a history of several thousand years and the Chinese language has an inexhaustible appeal; I feel confident that more literary works written in Chinese or one of the Chinese languages [hanyu huo huayu] will be rewarded in the future. [...] It is inevitable [that the prize be politically tendentious]; the judgments made in awarding a literary prize always have a certain human or even political background. This isn't worth criticising; I think anyone with a brain may form their own judgment." The end of the interview is reprinted in a wire from the dissident news agency Renminbao, available online: http://renminbao.com/rmb/articles/2000/10/14/4458pb.html (28 May 2010). This report was subsequently denied by the Chinese government.

5. C. T. Hsia, "Obsession with China: The moral burden of Chinese literature," A History of Modern Chinese Fiction, 3rd ed., Bloomington, Indiana University Press, 1999, pp. 536-7. It is unfortunate that while this study, which bears a deep imprint of Cold War aesthetics, is viewed with increasing circumspection in the West, it has gained wide currency in China as the standard "Western" narrative of the rise of modern Chinese literature.

6. Fredric Jameson, "Third-World Literature in the Era of Multinational capitalism," Social Text, no. 15 (1986), p. 65.

7. Julia Lovell, The Politics of Cultural Capital, Honolulu, University of Hawaii Press, 2006. "The Nobel committee, which claims to be honoring a Chinese writer for his 'universal validity,' only mentions by name his works related to China, which happens to be one of the last great stumbling blocks to the global victory of liberal democratic capitalism." ( $p$. 178)

8. See Kuang Mingyan, Zhang Jun (eds), Nuobeier wenxue jiang mingzhu sudu (The great works of the Nobel Prize for literature: a fast reader), Beijing, Huawen chubanshe, 2009. The book provides extracts from works of all laureates from 1901 to 2008, but does not mention the 2000 laureate even by name. Similarly, a long interview conducted by Southern Weekend during Gao's visit to Hong Kong in 2008 remained unpublished.

9. See, for example, the articles collected on the blog East South North West: http://www.zonaeuropa. com/culture/c20061214_1.htm (28 May 2010). Southern Weekend (Nanfang Zhoumo) continuously treated the subject with interest, publishing a substantial analysis of Kubin's views by Swedish sinologist Torbjorn Lodén and Peking University Professor Chen Pingyuan on 5 April 2007 (cover of the culture section), and another long interview with W. Kubin on 27 November 2008, entitled "Xiandai xing wanquan shi yige cuowu: Gubin yan zhong de 20 shiji Zhongguo wenxue" (Modernity was a complete mistake: 20th c. Chinese literature in the eyes of W. Kubin). 
many Chinese intellectuals, of worldwide recognition for literature written in their language or their country. Incidentally, Kubin on this occasion dismissed a question about the value of Gao Xingjian's writing as "a joke." ${ }^{(1)}$ Most recently, the 2009 Frankfurt Book Fair, at which "China" was invited as "guest of honour," once more stoked passions when certain writers were not included in the official delegation. ${ }^{(I I)}$ While these discussions are revealing and stimulating, the present feature takes an explicitly non-normative approach to literature, including to the texts themselves. Polemics such as those surrounding the Nobel Prize or W. Kubin's views are reminiscent of a time in which the study of literature was devoted to demonstrating its "beauty," and literature as a discipline was a branch of aesthetics rather than of social sciences. Much of the indignation about the Nobel Prize (awarded, no less, by a group of old, white, European males who purport to "judge" the merits of world literature) stems from excessive naivety as to the pureness of its ideals - it is after all, as Zhu Rongji slyly suggested, not different from other, often hotly disputed, literary prizes and their intrigues, including in China (the four-yearly Mao Dun prize probably tops the list). In these post-Bourdieusian, post-Jaussian times, most scholars have come to work with a far more prosaic understanding of literary texts and their institutional status, which is not seen to be derived from visionary philosophical insights couched in aesthetically sublime forms by a prophet-like writer in the romantic tradition, but as a complex interaction between social expectations and representations, the cultural "field," and its power plays.

However, these debates have raised welcome questions about the self-representation of Chinese literature and its place in the world, in a context in which the relevance of literature itself to the contemporary world is constantly called into doubt. The outcry in China over the Nobel Prize, in strong contrast with Taiwan and Hong Kong speaks to the continued expectation in official circles that literature must be "representative" of the nation. In an interview conducted by Julia Lovell, Lao She's son Shu Yi, then director of the National Literature Museum, exclaims: "Why don't they give the Prize to China?" ${ }^{(12)}$, in a striking contrast with the Nobel committee's own statements that prizes are purely individual, and even explicit desire to reward individuals somehow at odds with their nation. ${ }^{(13)}$

Similarly, Wolfgang Kubin's views are of interest not because they disqualify contemporary fiction, but because they raise certain substantive questions: in this respect the often sympathetic echo of Kubin's views in the Chinese press can be seen as a manifestation of not only a secular inferiority complex, but also an ongoing concern among Chinese intellectuals about certain trends in contemporary society (including, but not limited to, China), such as commercialisation, intellectual parochialism, and reverence for officialdom and state-sanctioned culture. Kubin highlights the lack of "cosmopolitanism" among contemporary Chinese writers, contrasting them with their Republican-era predecessors, who often read news and fiction from around the world. ${ }^{(14)} \mathrm{He}$ finds fault with Chinese literature's continued subordination to politics (after 1949) and now also to commercial success (since 1992): because of institutions such as the Writers' Association (recently buttressed by a move to include young best-selling authors such as Guo Jingming), ${ }^{(15)}$ no contemporary writer living in China has tackled issues such as Tibet or Tiananmen. Like more than a few Chinese writers, Kubin deplores the corruption of the Chinese language by bureaucratic Mao-speak, which he likens to German under the Third Reich (in an implicit reference to Victor Klemperer's seminal study Lingua Tertii Imperii), a problem he believes is compounded by the lack of proper editorial work by Chinese publishers. He points to the contemporary novel

10. "Deguo hanxuejia quanwei lingwai yizhi yan kan xiandangdai Zhongguo wenxue" (German authoritative sinologist casts a different eye on modern and contemporary Chinese literature), Deutsche Welle, 11 November 2006, http://www.dwworld.de/dw/article/0,,2249278,00.html (28 May 2010).

11. German weekly Die Zeit has compiled an excellent online feature on the Book Fair available at : http://www.zeit.de/themen/kultur/frankfurter-buchmesse-2009/index (31 May 2010).

12. Julia Lovell, The Politics of Cultural Capital, op. cit., p. 179-180.

13. In this respect, one might equally submit that the Nobel committee has manifested its own quite consistent agenda over the last quarter of a century (roughly since Wole Soyinka's prize in 1986), systematically rewarding writers who are at odds with their "national culture" and politics: whether "Western" (Dario Fo, Elfriede Jelinek, José Saramago, Harold Pinter, and others stand out for their critical views on Western democracy, colonialism, and capitalism) or from what is now termed the "non-West": Orhan Pamuk, V. S. Naipaul, Naguib Mahfouz, and especially Ōe Kenzaburō, whose critical views on Japan seem to have been positively chosen to make up for the Kawabata fauxpas of 1968 (Wendy Larson describes the Academy's commending of Kawabata Yasunari for expressing "the essence of the Japanese Mind" as "racist ignorance"; it is certainly safe to say that such a pronouncement would no longer be considered politically correct today; see Wendy Larson, art cit., p. 147)

14. One might rightfully object, as pointed out by Gregory Lee (quoted by Julia Lovell), that when Pound borrows from China he is hailed as a modernist, but when May Fourth writers borrowed from the West, their works were dismissed as imitations. Gao has often suffered from this attitude. See G. Lee, Troubadours, Trumpeters, Troubled Makers, London, Hurst and Co., 1996, p. 79.

15. When, after Ba Jin's death, Tie Ning was elected as the new chairperson of the Writers' Association, she undertook to massively "recruit" young writers and internet writers into its ranks. Zhang Yueran, Guo Jingming and several other "post-80" stars joined on 27 September 2007 at the invitation of Wang Meng. See Zhang Ying, "Zuoxie 'kuo zhao' la" (The Writers' Association 'recruits widely'), Nanfang Zhoumo, 8 November 2011, p. D21. Han Han characteristically mocked their sycophantic behaviour and stated he would never join, because "I believe a real artist should always be independent, and never le himself be enrolled in an organization." in "Han Han: juedui bu jiaru Zuoxie" (Han Han: I will absolutely not join the Writers' Association), Nanfang Zhoumo, 8 November 2011, p. D22. One may hypothesize that the perennial duality of the Chinese literary scene has thus been extended to the "post-80s".. 
and its continued emulation of "magic realism" by writers such as Mo Yan - a critique reminiscent of Ziauddin Sardar (Postmodernism and the other, 1998), who accuses the genre of repackaging exoticism for post-colonial readers - as a source of stagnation, in particular the systematic use of allegory to convey political messages, which he believes impedes literary innovation. ${ }^{(16)}$

The choice of Gao Xingjian for this special feature of China Perspectives therefore relates to his engagement with many of the issues that have been at the centre of heated debates over modern Chinese literature, and which is reflected in the collection of articles. Opening the issue, Noell Dutrait's paper is devoted to Gao's intellectual stance as a writer "without -isms," related to what he sees as Chinese literature's main problem throughout the twentieth century: its excessive polarisation by politics and collectives, and the repeated injunction for writers to take a stance for or against a government or ideology, or in defence of China as a nationstate. This is reminiscent of Li Zehou's reflection on the repeated subordination of "Enlightenment" (qimeng) to "national salvation" (juwang). Gao thus pleads for individuality and rejects any national dimension to literature, stating his connexion with China only in terms of language (and even that attachment is not exclusive, as he also writes in French). ${ }^{(17)}$

Sy Ren Quah, re-examining Gao's "experimental plays" of the 1980s, finds that a close analysis of how China is "framed" in The Other Shore reveals subtle allusions to the Cultural Revolution and other past political traumas of the People's Republic. In this, as in other plays, Gao sets himself off from more traditional, epic "scar" writers by using modernist forms to make sense of an absurd series of historical events.

Yinde Zhang, in his analysis of Soul Mountain and One Man's Bible, situates Gao within the context of roots literature, also popular in the 1980s, which, as underscored by Julia Lovell, is a movement usually seen as "fundamentally implicated in the intellectual search for a strong Chinese identity" and thus as yet another example of "obsession with China." ${ }^{(18)}$ Yinde Zhang, however, highlights the parallel between forgotten cultures and forgotten historical events, concluding that Gao's symmetrical quests never provide access to a stable truth or identity, but rather diffract into complex constructions of personal experiences of guilt, survival, and forgetting.

Sebastian Veg's article, by comparing Gao with Ōe Kenzaburō , attempts to take him out of a purely Chinese context, while highlighting the distrust, shared by two Asian writers, of Western modernity, which subordinates the individual to the nation and culture to development. Despite their different attitudes to politics, they both favour a position for the writer on the social and geographical margins.

The feature is completed by an unpublished essay by Gao Xingjian, in which he pleads for a less negative view of history and artistic creation, one that is not underpinned by Hegelian and Marxist dialectics. Aesthetic creation, he argues, should be based on "cognition and recognition" rather than on dialectic subversion of tradition. ${ }^{(19)}$

It may seem paradoxical to focus on a writer as "marginal" as Gao Xingjian to reflect on the status of contemporary literature in China. ${ }^{(20)}$ However, ten years after the first Chineselanguage Nobel Prize, the controversy shows no sign of abating, a fact that ultimately speaks to the continued importance of literature in the intellectual debate in China. -

16. See "Xiandai xing wanquan shi yige cuowu," art. cit., and "Wolfgang Kubin: le romanicer chinois type est un inculte" (The typical Chinese fiction writer has no culture), Books Magazine, no. 10, November-December 2009, http://www.booksmag.fr/magazine/ a/wolfgang-kubin-le-romancier-chinois-type-est-un-inculte.html (28 May 2010).

17. Gao Xingjian's status as a French writer falls outside the scope of this feature: see Claire Conceison, "The French Gao Xingjian, Bilingualism, and Ballade nocturne," Xianggang xiju xuekan (Hong Kong Drama Review), vol. 8 (2009), pp. 303-322.

18. Julia Lovell, op. cit., p. 168.

19. Several of these articles and Gao's essay were originally presented at a conference coorganised in 2008 by the Chinese University of Hong Kong and the French Centre for Research on Contemporary China, with the support of the d'Alembert Fund of the French Foreign Ministry. The editors would like to express their thanks to Gilbert Fong, the coorganiser of the conference, and Noël Dutrait for his continued support, as well as to Jean-Luc Bidaux and C. K. Lam, the librarians responsible for the Gao collections at Aixen-Provence and CUHK, Gao Xingjian, Tang Shu-wing and Pierre Haski for providing illustrations.

20. See also the special issue of Modern Chinese Literature and Culture devoted to Gao in 2002 (vol. 14, no. 2). 